\title{
Osmoregulatory transporter ProP influences colonization of the urinary tract by Escherichia coli
}

\author{
Doreen E. Culham, ${ }^{1}$ Cheryl Dalgado, ${ }^{1}$ Carlton L. Gyles, ${ }^{2}$ Daniel Mamelak, ${ }^{1}$
} Shawn MacLellan' ${ }^{1}$ and Janet M. Wood ${ }^{1}$

\author{
Author for correspondence: Janet M. Wood. Tel: +1519824 4120 ext. 3866. Fax: +1 5198371802 . \\ e-mail: jwood@micro.uoguelph.ca
}

Department of Microbiology ${ }^{1}$ and Department of Pathobiology2, University of Guelph, Guelph, ON. Canada N1G 2W1

\begin{abstract}
Osmoregulatory transporters ProP and ProU mediate the use of betaines as osmoprotectants by Escherichia coli. Glycine betaine and proline betaine are present in mammalian urines. Betaine uptake may therefore facilitate the growth of $E$. coli in the urinary tract, an environment of fluctuating osmolality. ProP transporter activity was approximately threefold higher in a pyelonephritis isolate, E. coli HU734, than in E. coli K-12. The growth rate of E. coli HU734 in aerated minimal salts medium was reduced twofold by $0.2 \mathrm{M}$ $\mathrm{NaCl}$ in the absence and by $0.55 \mathrm{M} \mathrm{NaCl}$ in the presence of glycine betaine. Maximal growth rate stimulation was achieved when glycine betaine was added at a concentration as low as $25 \mu \mathrm{M}$. Deletion of the prop locus impaired the growth rate of E. coli HU734 in human urine but not in minimal medium supplemented with $\mathrm{NaCl}(0.4 \mathrm{M})$, with or without glycine betaine $(0.1 \mathrm{mM})$. The expression of pyelonephritis-associated $(P)$ pili was reduced when $E$. coli HU734 was cultured in a rich culture medium (LB) of elevated salinity. The proP lesion had no influence on P pilus expression in vitro or on the recovery of bacteria from the kidneys of inoculated mice. However, it did reduce their recovery from the bladders of inoculated mice 100-fold. These data provide the first direct evidence that osmoprotective betaine accumulation and transporter ProP are pertinent to both growth in human urine and colonization of the murine urinary tract by uropathogenic $E$. coli.
\end{abstract}

Keywords: osmoregulation, glycine betaine, urinary tract infection, Escherichia coli, ProP

\section{INTRODUCTION}

Kunin (1987) described urine as a 'variable, but generally good, culture medium', indicating that poor iron availability, high organic acid levels, low $\mathrm{pH}$ and variable osmolality may limit the survival and growth of Escherichia coli in the human urinary tract. Since E. coli causes most ascending infections of the unobstructed human urinary tract (Warren, 1996) and mice are used in an experimental model for human urinary tract infection (Johnson \& Russell, 1996), the ability of E. coli to grow in the human and murine urinary tracts has clinical importance.

Abbreviations: AC, L-azetidine-2-carboxylic acid; Amp, ampicillin; DHP, 3,4-dehydro-D,L-proline; TC, triphenyltetrazolium chloride.

The GenBank accession number for the sequence determined in this paper is U75904.
The osmolality of human urine may vary from approximately 0.04 to $1.4 \mathrm{~mol} \mathrm{~kg}^{-1}\left(0.5-0.8 \mathrm{~mol} \mathrm{~kg}^{-1}\right.$ with a normal diet and fluid intake) (Ross \& Neely, 1983). Urine osmolalities up to $3 \mathrm{~mol} \mathrm{~kg}{ }^{-1}$ have been detected in rats and mice (Schmidt-Nielsen et al., 1983; Loeb \& Quimby, 1989). E. coli is moderately salt-tolerant, the most salt-tolerant human isolates growing in minimal medium supplemented with up to $0.7 \mathrm{M} \mathrm{NaCl}$ (hence at an osmolarity in excess of $1.4 \mathrm{~mol} \mathrm{~kg}^{-1}$ ) (Kunin et al., 1992). Although they varied in salt tolerance, no correlation between urinary tract origin and salt tolerance was found among 301 clinical E. coli isolates. Salt tolerance was defined as the maximum $\mathrm{NaCl}$ concentration at which there was $50 \%$ growth (optical density after $48 \mathrm{~h}$ ) compared to a control culture in minimal medium without added $\mathrm{NaCl}$ (Kunin et al., 1992). These observations suggest that the osmolality of human urine varies within the range tolerated by most 
E. coli isolates in vitro whereas the osmolality of rodent urine may exceed the osmotolerance of $E$. coli. However, it remains possible that modulation of growth rate by urine osmolality influences the population density of $E$. coli in the urinary tract.

In E. coli $\mathrm{K}-12$, osmoregulatory transporters and channels modulate cytoplasmic osmolality by mediating the active accumulation or release of osmoprotectants, available in the external medium, which are particularly compatible with the functions of cellular macromolecules (Csonka \& Epstein, 1996). The osmoprotectants used by $E$. coli $\mathrm{K}-12$ include proline, glycine betaine ( $N$-trimethyl glycine), proline betaine $(N$ dimethyl proline or stachydrine) and ectoine (1,4,5,6tetrahydro-2-methyl-4-pyrimidinecarboxylic acid). Uptake of these compounds is mediated by transporters ProP and ProU. Transcription of proP and proU is induced when $E$. coli is cultured in hypertonic media and both transporters are activated when cells are exposed to osmotic upshifts.

Current research on the role of bacterial osmoadaptation in urinary tract infection was triggered by the observation that urinary glycine betaine and proline betaine provide osmoprotection to E. coli (Chambers \& Kunin, 1987). Glycine betaine raises the salt tolerance of $E$. coli to $1 \mathrm{M}$ (according to the criterion described above; Kunin et al., 1992). Defects in genetic loci proP and proU impaired (1) the accumulation of diverse betaines by E. coli K-12 (Randall et al., 1995), (2) the ability of glycine betaine to stimulate the growth (extent) of $E$. coli K-12 in artificial urine (Culham et al., 1994) and (3) the growth of E. coli $\mathrm{K}-12$ in authentic (presumably betaine-containing) urine (Kunin et al., 1992). However, E. coli strains isolated from the human urinary tract were not distinguished from other clinical isolates by their ability to utilize betaines as osmoprotectants in vitro (Kunin et al., 1992; Culham et al., 1994). Culham et al. (1994) examined the distribution and expression of genes encoding osmoregulatory transporters ProP and ProU in 61 different E. coli strains, 28 from the human urinary tract and 33 with other human origins. All contained and expressed the proU locus; evidence for expression of proP by one (infantile diarrhoea) isolate was equivocal. Thus, betaine uptake via ProP and/or ProU can contribute to the osmotolerance of clinical $E$. coli isolates. However, the cited observations do not indicate whether ProP or ProU is active in uropathogenic bacteria within their mammalian hosts or whether the activities of those transporters contribute to bacterial growth within the urinary tract.

In addition to directly influencing bacterial growth in the urinary tract, osmoregulatory mechanisms may indirectly influence urinary tract infection by affecting the expression of virulence determinants. $P$ (pyelonephritis-associated) pili are expressed by $81 \%$ of $E$. coli isolates from pyelonephritis patients whose risk of infection is not increased by underlying medical or anatomical conditions. They are implicated in bacterial adhesion to urinary tract tissues (Donnenberg \& Welch, 1996). The effects of hypertonic media on pap (P pilus) operon transcription have not been reported despite extensive analyses of that system (van der Woude et al., 1996). However, Kunin et al. (1994) used electron microscopy of negatively stained preparations and haemagglutination to detect a reduction in $\mathrm{P}$ pilus expression when pyelonephritis isolates of $E$. coli were cultured on rich medium (trypticase soy agar) supplemented with $0.4-0.8 \mathrm{M} \mathrm{NaCl}$.

Our goal is to identify direct and indirect effects of environmental osmolality and of osmoregulatory betaine accumulation on the ability of uropathogenic $E$. coli strains to infect the urinary tract. Pyelonephritis isolate E. coli HU734 was used to develop the murine model for ascending urinary tract infection and to demonstrate that $P$ pili can facilitate colonization of the murine urinary tract (Hagberg et al., 1983a, b). It expresses genetic loci analogous to the proP and proU loci of $E$. coli K-12 (Culham et al., 1994). This paper describes deletion of the proP locus from E. coli HU734 and analyses of the effects of osmolality, glycine betaine and the proP lesion on bacterial growth, $\mathrm{P}$ pilus expression and colonization of the murine urinary tract.

\section{METHODS}

Media and growth measurements. Bacterial culture media included LB (Miller, 1972), LB-N (LB medium from which $\mathrm{NaCl}$ was omitted) and MOPS minimal medium (Neidhardt et al., 1974). MOPS medium was supplemented, unless otherwise stated, with D-glucose $(0.2 \%, \mathrm{w} / \mathrm{v})$ as carbon source, $\mathrm{NH}_{4} \mathrm{Cl}(9.5 \mathrm{mM})$ as nitrogen source, amino acids $\left(50 \mu \mathrm{g} \mathrm{ml}^{-1}\right)$ to meet auxotrophic requirements and thiamin $\left(1 \mu \mathrm{g} \mathrm{ml}^{-1}\right)$. TTC (triphenyltetrazolium chloride) indicator medium for proline utilization was prepared as described by Bochner \& Savageau (1977) and supplemented with proline $(200 \mathrm{mM})$ and cysteine $\left(50 \mu \mathrm{g} \mathrm{ml}^{-1}\right)$. Saline was $0.85 \%(\mathrm{w} / \mathrm{v})$ $\mathrm{NaCl}$. The osmolalities of selected media were determined with a vapour pressure osmometer (Wescor) to be: LB, $0.4 \mathrm{~mol} \mathrm{~kg}^{-1}$; LB plus $0.3 \mathrm{M} \mathrm{NaCl}, 1.0 \mathrm{~mol} \mathrm{~kg}^{-1}$; LB plus $0.6 \mathrm{M} \mathrm{NaCl}, 1.6 \mathrm{~mol} \mathrm{~kg}{ }^{-1}$; MOPS medium, $0.20 \mathrm{~mol} \mathrm{~kg}^{-1}$; MOPS medium plus $0.2 \mathrm{M} \mathrm{NaCl}, 0.56 \mathrm{~mol} \mathrm{~kg}^{-1}$; MOPS medium plus $0.4 \mathrm{M} \mathrm{NaCl}, 0.94 \mathrm{~mol} \mathrm{~kg}^{-1}$; MOPS medium plus $0.6 \mathrm{M} \mathrm{NaCl}, 1.41 \mathrm{~mol} \mathrm{~kg}^{-1}$; MOPS medium plus $0.8 \mathrm{M} \mathrm{NaCl}$, $1.77 \mathrm{~mol} \mathrm{~kg}^{-1}$; MOPS medium plus $1.0 \mathrm{M} \mathrm{NaCl}$, osmolality exceeded the detection limit of the osmometer.

Rates of bacterial growth in shaken cultures were determined as follows. Overnight LB cultures were added as inocula $(0.5 \mathrm{ml})$ to $25 \mathrm{ml} \mathrm{LB}$ medium in a $125 \mathrm{ml}$ flask and incubated overnight. The cells were harvested by centrifugation, washed with saline and resuspended in $10 \mathrm{ml}$ saline. The resulting suspension was used to inoculate $25 \mathrm{ml}$ test cultures in $125 \mathrm{ml}$ sidearm flasks (sidearm internal diameter, $1 \mathrm{~cm}$ ) to an $\mathrm{OD}_{600}$ of $0 \cdot 1$. Cultures were incubated at $37^{\circ} \mathrm{C}$ with rotary shaking at 200 r.p.m. and the $\mathrm{OD}_{600}$ was recorded at $30 \mathrm{~min}$ intervals until it exceeded 1.0 (or stationary phase was reached at a lower optical density). Growth rates were determined by linear regression analysis of data defining the exponential portion of each growth curve (log absorbance versus time). Each growth condition was tested in triplicate and each experiment was performed at least twice. The growth of bacteria in stationary cultures was monitored as described 
Table 1. E. coli strains and plasmids

\begin{tabular}{|c|c|c|}
\hline $\begin{array}{l}\text { Strain or } \\
\text { plasmid }\end{array}$ & Relevant characteristics & Source and/or derivation \\
\hline \multicolumn{3}{|l|}{ Strains } \\
\hline $\mathrm{DH} 5 \alpha$ & $\begin{array}{l}\mathrm{K}-12 \mathrm{~F}^{-} \phi 80 \mathrm{~d} l a c Z \Delta \mathrm{M} 15 \Delta(\text { lacZYA-argF }) \mathrm{U} 169 \text { recA1 endA1 hsdR17 } \\
\left(\mathrm{r}_{\mathrm{k}}^{-} \mathrm{m}_{\mathrm{k}}^{+}\right) \operatorname{supE44} \lambda^{-} \text {thi-1 gyrA relA1 }\end{array}$ & BRL \\
\hline HU734 & GR12 lacZ & G. Reid (Hagberg et al., 1983a) \\
\hline HU742 & HU734 pap & S. Hull (Hagberg et al., 1983a) \\
\hline S17-1 גpir & thi pro hsdR hsdM $M^{+}$recA rp4-Tc::Mu-Km::Tn7 $\lambda$ pir & P. Goodwin (Herrero et al., 1990) \\
\hline SK2881 & $\mathrm{K}-12 \mathrm{~F}^{-}$gal leuC thi aroD6 $T 1^{\mathrm{R}}$ bsdR 4 recA1 sbc15 endA & S. Hull (Klann et al., 1994) \\
\hline SY327 גpir & $\mathrm{K}-12 \Delta($ lac pro $) \arg E(A m)$ rif nalA recA56 $\lambda$ pir & J. Kaper (Miller \& Mekalanos, 1984) \\
\hline WG444 & $\mathrm{K}-12 \Delta(p u t P A) 101$ srl-300::Tn10 & Culham et al. (1994) \\
\hline WG445 & K-12 $\Delta($ putPA $) 101 \Delta($ proP-mel $) 212$ srl-300:: Tn10 & Culham et al. (1994) \\
\hline WG484 & $\mathrm{K}-12$ srl-300::Tn10 & Culham et al. (1994) \\
\hline WG541 & HU734 $\Delta(p u t P A) 566$ & This work \\
\hline WG671 & WG541 proP218 & This work \\
\hline \multicolumn{3}{|l|}{ Plasmids } \\
\hline pAGK2 & pACYC184 pap ${ }^{+}$ & Klann et al. (1992) \\
\hline pCVD442 & oriR6K mobRP4 $\mathrm{Gm}^{\mathrm{R}} s a c B$ & J. Kaper (Donnenberg \& Kaper, 1991) \\
\hline pDC10 & pGEM4 proP $P^{+}$ & Culham et al. (1993) and see text \\
\hline pDC60 & pGEM4 proP218 & This work \\
\hline pDC62 & pJQ200mp18 proP218 & This work \\
\hline pDC66 & pCVD442 proP218 & This work \\
\hline pJQ200mp18 & oriP15A mobRP4 Amp ${ }^{\mathrm{R}} s a c B$ & M. Hynes (Quandt \& Hynes, 1993) \\
\hline
\end{tabular}

above with the following exceptions. Cultures were incubated at $37^{\circ} \mathrm{C}$ without agitation. At $3-4 \mathrm{~h}$ intervals after inoculation cultures were sampled, $\mathrm{OD}_{600}$ values were determined and $\mathrm{LB}$ plates were inoculated with culture dilutions to determine viable counts. No culture was sampled more than once, each determination was made in duplicate and each experiment was performed twice.

For measurements of bacterial growth in urine, concentrated, first-voided morning urine was collected from six healthy adult volunteers following overnight $(14 \mathrm{~h})$ fluid and food deprivation. The pooled urine was centrifuged at 7000 r.p.m. at $4{ }^{\circ} \mathrm{C}$ for $10 \mathrm{~min}$ (Sorvall GSA rotor) and sterilized by filtration through 0.45 $\mu \mathrm{m}$ pore size filters (Gelman Sciences). Bacteria from overnight LB cultures were inoculated into $25 \mathrm{ml}$ aliquots of urine in $125 \mathrm{ml}$ culture flasks (three replicates per strain tested) at initial densities of approximately 1000 c.f.u. $\mathrm{ml}^{-1}$. Cultures were incubated at $37^{\circ} \mathrm{C}$ with rotary shaking at 150 r.p.m. Growth was monitored in two ways : (1) cell density was measured by monitoring $\mathrm{OD}_{600}$ at $30 \mathrm{~min}$ intervals during exponential-phase growth (optical density range approximately $0 \cdot 1-1 \cdot 0$, see Fig. 2 ), and (2) viable counts were monitored at $60 \mathrm{~min}$ intervals by inoculating LB plates with appropriate culture dilutions. After $24 \mathrm{~h}$, the purity of each culture was verified by inoculating phenotype-specific media.

Bacterial strains. The $E$. coli strains used for this study are listed in Table 1. Strain HU734, a lacZ derivative of acute human pyelonephritis isolate GR12, has the following properties: streptomycin and spectinomycin resistance and cysteine auxotrophy, serotype $075: \mathrm{K} 5$, possession of both type 1 and $P$ pili (the latter encoded by a single pap operon), carriage of a ColV plasmid, resistance to killing by human and mouse serum, and failure to produce haemolysin (Hagberg et al., 1983a; Mamelak, 1994). Plasmid pAGK2 consists of a $10 \mathrm{~kb}$
ClaI fragment including the pap-3 operon from E. coli GR12 (HU734) inserted into the ClaI site in the tet gene of vector pACYC184 (Klann et al., 1992; S. Hull, personal communication). The identity and purity of each culture was tested by culturing bacteria on the following media: LB medium; LB medium supplemented with ampicillin (Amp, 50 or $\left.100 \mu \mathrm{g} \mathrm{ml}^{-1}\right)$, chloramphenicol $\left(30 \mu \mathrm{g} \mathrm{ml}^{-1}\right)$, kanamycin $\left(50 \mu \mathrm{g} \mathrm{ml}^{-}\right)$, streptomycin $\left(100 \mu \mathrm{g} \mathrm{m}^{-1}\right)$ or tetracycline ( $25 \mu \mathrm{g} \mathrm{m}^{-1}$ ) (as indicated by the bacterial genotype); MOPS medium with and without required amino acids $\left(50 \mu \mathrm{g} \mathrm{ml}^{-1}\right)$; TTC medium and lactose MacConkey agar. Cultures were also tested with the radial streak assay using the toxic proline analogues L-azetidine-2-carboxylic acid (AC) and 3,4-dehydro-D,L-proline on MOPS medium with and without supplemental $\mathrm{NaCl}(0.3 \mathrm{M})$ as described by Grothe et al. (1986).

E. coli WG541 [HU734 $\Delta(p u t P A) 566]$ was isolated essentially as described by Wood (1981). After overnight growth in MOPS medium, cells of strain HU734 were harvested by centrifugation, washed with saline and resuspended in saline to a density of approximately $2 \times 10^{9}$ cells $\mathrm{ml}^{-1}$. Aliquots $(0.1 \mathrm{ml})$ of the resulting suspension were spread on MOPS medium plates supplemented with L-cysteine $\left(50 \mu \mathrm{g} \mathrm{ml}^{-1}\right)$ and AC $\left(25 \mu \mathrm{g} \mathrm{ml}^{-1}\right)$. After incubation of the plates for $48 \mathrm{~h}$ at $37^{\circ} \mathrm{C}, 500$ of the resulting colonies were transferred to TTC indicator medium. Strain WG541 was one of three isolates which yielded only white $(p u t)$ colonies after restreaking on TTC medium. All three were devoid of proline dehydrogenase activity as indicated by the 0 -aminobenzaldehyde assay (Graham et al., 1984) and sensitive to inhibition by 3,4dehydro-D,L-proline (DHP) as indicated by the radial streak test (Wood, 1981; Grothe et al., 1986). Unlike that of its parent, chromosomal DNA from strain WG541 failed to support amplification of a $201 \mathrm{bp}$ DNA fragment internal to putP, a $461 \mathrm{bp}$ fragment of the put intergenic region or a 
628 bp DNA fragment internal to putA (PCR performed as described by Culham et al., 1994).

Molecular biological manipulations were carried out as described by Sambrook et al. (1989). Transformations were done in E. coli strain DH5 $\alpha$ and transformants were selected on LB plates containing $100 \mu \mathrm{g} \mathrm{Amp} \mathrm{ml}{ }^{-1}$ (plasmids based on pGEM4 or pCVD442) or $15 \mu \mathrm{g}$ gentamicin $\mathrm{ml}^{-1}$ (plasmids based on PJQ200mp18) unless otherwise indicated. Deletion proP218 was created by digesting plasmid pDC10 (isolated in the same manner as pDC15 (Culham et al., 1993) with restriction endonucleases EagI and MfeI, blunt-ending and religating the larger $5 \mathrm{~kb}$ fragment to create pDC60. This removed a DNA fragment extending from $59 \mathrm{bp}$ upstream to $44 \mathrm{bp}$ downstream of proP. Plasmid pDC60 was digested with restriction endonucleases $S m a \mathrm{I}$ and $\mathrm{NruI}$ and the $2 \cdot 1 \mathrm{~kb}$ fragment (containing chromosomal DNA flanking the proP deletion) was isolated and ligated into the $S m a$ I site of vector pJQ200mp18 to create plasmid pDC62. This plasmid was then digested with SstI and the $2 \mathrm{~kb}$ fragment (containing $747 \mathrm{bp}$ upstream and $1253 \mathrm{bp}$ downstream of the proP deletion) was ligated into the SstI site of vector pCVD442 to create plasmid pDC66 (transformation into E. coli S17-1 $\lambda$ pir).

Deletion proP218 was introduced to strain WG541 by allelic replacement essentially as described by Mobley et al. (1993). Strains WG541 and S17-1 $\lambda$ pir(pDC66) were inoculated from overnight $\mathrm{LB}$ cultures into $10 \mathrm{ml} \mathrm{LB}$ to an $\mathrm{OD}_{600}$ of 0.2 and incubated at $37^{\circ} \mathrm{C}$ (WG541) or $30^{\circ} \mathrm{C}$ [S17-1 $\lambda$ pir(pDC66)] with aeration to an $\mathrm{OD}_{600}$ of 0.8 . Amp $\left(100 \mu \mathrm{g} \mathrm{ml}^{-1}\right)$ was added to cultures of the latter strain. Cells were collected by centrifugation and washed twice in an equal volume of LB. Aliquots $(1 \mathrm{ml})$ of each culture were added to $9 \mathrm{ml} \mathrm{LB}$ and filtered through a $47 \mathrm{~mm}$ diameter, $0.45 \mu \mathrm{m}$ pore size nitrocellulose filter (Gelman Sciences). The resulting filter was transferred to an LB plate, incubated for $3 \mathrm{~h}$ at $30^{\circ} \mathrm{C}$ and transferred to a tube containing $2 \mathrm{ml}$ saline. Cells were washed from the filter by vortex mixing and $100 \mu \mathrm{l}$ aliquots were spread on MOPS medium plates containing L-cysteine $\left(50 \mu \mathrm{g} \mathrm{ml}^{-1}\right)$ and Amp $\left(100 \mu \mathrm{g} \mathrm{ml}^{-1}\right)$. The single resulting transconjugant was grown in Amp-supplemented LB medium overnight, subcultured to a density of approximately $10^{6}$ c.f.u. $\mathrm{ml}^{-1}$ in five aliquots $\mathrm{LB}\left(10 \mathrm{ml}\right.$ each) and incubated at $37^{\circ} \mathrm{C}$ for $5 \mathrm{~h}$ to a density of approximately $10^{9}$ c.f.u. $\mathrm{ml}^{-1}$. Dilutions of each culture $(0 \cdot 1 \mathrm{ml})$ were spread on LB-N medium containing sucrose $[5 \%(\mathrm{w} / \mathrm{v})]$. After incubation at $30^{\circ} \mathrm{C}$ for $18 \mathrm{~h}, 36$ colonies were selected and screened for loss of Amp resistance (30 were Amp-sensitive). Chromosomal DNA was isolated from 10 of the Amp-sensitive colonies and analysed by DNA amplification for the presence of proP218. Primers corresponding to nucleotides $1302-1321$ and 1557-1539 within proP (numbering from the sequence with accession number M83089) directed PCR amplification of a 256 bp DNA fragment when wild-type proP DNA was used as PCR template. Primers corresponding to sequences flanking proP (nucleotides 124-150 and 2037-2012) directed amplification of a 311 bp DNA fragment when proP218 DNA was used as template. Strain WG671 was one of six among the ten tested isolates which carried proP218 and not the wild-type allele.

DNA sequence analysis. Templates for sequencing of the proP locus in E. coli HU734 were synthesized by PCR amplification using synthetic oligonucleotide primers based on the known sequence of the E. coli K-12 proP locus (accession number M83089). Sequence analysis was then conducted using the same primers by Mobix (Hamilton, ON, USA). Overlapping fragments extending from 282 bp upstream to 79 bp downstream of the proP ORF were sequenced, yielding a full sequence of one DNA strand. PCR and sequencing were repeated to confirm the observed differences between $E$. coli K-12 and E. coli HU734.

Transport assays. The activities of transporters PutP, ProP and ProU were estimated by measuring the uptake of osmoprotectant proline. Bacteria were cultured for transport measurements and initial rates of L-proline uptake were estimated essentially as described by Milner et al. (1988). Bacteria were cultured in MOPS medium with glycerol $\left(4 \mathrm{mg} \mathrm{ml}^{-1}\right)$ as carbon source, $\mathrm{NH}_{4} \mathrm{Cl}(9.5 \mathrm{mM})$ as nitrogen source, cysteine $\left(50 \mu \mathrm{g} \mathrm{ml}^{-1}\right)$, thiamin $\left(1 \mu \mathrm{g} \mathrm{ml}^{-1}\right)$ and other supplements as specified. Reaction mixtures (final volume $0.5 \mathrm{ml}$ ) included MOPS medium (devoid of $\mathrm{NH}_{4} \mathrm{Cl}$ and amino acids), glucose (11 mM), supplementary $\mathrm{NaCl}$ (as indicated), uniformly labelled L- $\left[{ }^{14} \mathrm{C}\right]$ proline (concentration as specified) and $0.1-0.3 \mathrm{mg}$ cell protein. Samples $(0.15 \mathrm{ml})$ were removed $20 \mathrm{~s}, 40 \mathrm{~s}$ and $60 \mathrm{~s}$ after initiation of the assay with $\left[{ }^{14} \mathrm{C}\right]$ proline. Wash solutions were the same as the corresponding transport assay media except that they lacked glucose and the radiolabelled substrate. Mean uptake rates, with standard errors, were determined for triplicate uptake assays and each experiment was performed at least twice.

Haemagglutination assays. Haemagglutination assays were conducted essentially as described by Old (1985). Erythrocytes were harvested from sheep blood by low-speed centrifugation (5000 r.p.m., $4^{\circ} \mathrm{C}, 10 \mathrm{~min}$, Sorvall SS34 rotor). The pellet was washed three times with saline and erythrocytes were suspended to a final concentration of $6 \%(\mathrm{v} / \mathrm{v})$ in Alsever's solution [containing D-glucose $\left(20.5 \mathrm{~g} \mathrm{l}^{-1}\right)$, sodium citrate dihydrate $\left(8 \mathrm{~g} \mathrm{l}^{-1}\right)$ and $\left.\mathrm{NaCl}\left(4 \cdot 2 \mathrm{~g} \mathrm{l}^{-1}\right)\right]$. Bacteria to be tested for haemagglutinating activity were suspended in saline to an $\mathrm{OD}_{600}$ of 15 , yielding titres of approximately $10^{10}$ c.f.u. $\mathrm{ml}^{-1}$ as determined by dilution plating on LB medium. That suspension and serial twofold dilutions in saline $(20 \mu \mathrm{l})$ were mixed with erythrocytes $(20 \mu \mathrm{l})$ and saline or $2 \%(\mathrm{w} / \mathrm{v}) \mathrm{D}$ mannose $(20 \mu \mathrm{l})$ in ceramic, deep-well dishes and haemagglutination was assessed visually. Erythrocytes failed to agglutinate in the absence of bacteria and in the presence of E. coli strain HU742 (pap).

Pilus extraction and SDSPAGE. Pili were extracted from $E$. coli strain HU734 (and control preparations were made from E. coli HU742) as follows. Bacteria were cultured by inoculating $25 \mathrm{LB}$ plates with $100 \mu \mathrm{l}$ (each) of an overnight LB culture and incubating for $24 \mathrm{~h}$ at $37^{\circ} \mathrm{C}$. Five millilitres $\mathrm{Na}$ MOPS buffer $(5 \mathrm{mM}, \mathrm{pH} 7)$ and a sterile paper clip were added to each plate and the bacteria were resuspended by agitation of the paper clip with a magnetic stirring platform. The cell suspensions were pooled, processed with a Waring Blender $(2 \times 2.5 \mathrm{~min})$ and centrifuged $\left(7000\right.$ r.p.m., $4^{\circ} \mathrm{C}$, $20 \mathrm{~min}$, Sorvall GSA rotor). The supernatant was centrifuged (18000 r.p.m., $4{ }^{\circ} \mathrm{C}, 30 \mathrm{~min}$, Beckman $45 \mathrm{Ti}$ rotor) to remove cellular debris and pili were harvested from the resulting supernatant by centrifugation $\left(40000\right.$ r.p.m., $4^{\circ} \mathrm{C}, 60 \mathrm{~min}$, Beckman 45Ti rotor). The resulting pellet was resuspended in water, lyophilized and solubilized for electrophoresis according to the procedure of McMichael \& Ou (1979). SDSPAGE was performed as described by Laemmli (1970) using $15 \% \mathrm{~T}$ and $2.6 \% \mathrm{C}$ and staining with Coomassie brilliant blue R.

Colonization of the murine urinary tract. The ability of E. coli strains to ascend the urinary tracts of female, CBA mice (Jackson Laboratories) was tested essentially as described by Hagberg et al. (1983a, b). Inocula were prepared by incubating LB cultures in Erlenmeyer flasks (culture volume $20 \%$ of flask 
volume) for approximately $17 \mathrm{~h}$ at $37^{\circ} \mathrm{C}$ without shaking to yield an $\mathrm{OD}_{600}$ value of $0 \cdot 5-0 \cdot 7$. Cells were harvested by centrifugation $(4000 \mathrm{~g}, 10 \mathrm{~min}$, room temperature) and gently resuspended at $1 / 200$ of the culture volume in saline. The purity of the culture was checked by inoculating appropriate media and the expression of $P$ pili was verified, during selected experiments, by testing for mannose-resistant haemagglutination. Mice, aged 6-8 weeks, were individually anaesthetized by exposure to methoxyfluorane (Janssen Pharmaceuticals) in a closed glass jar for 2-2.5 min. Fifty microlitres of the inoculum (approximately $10^{8}$ c.f.u.) was instilled into the urinary tract of each mouse over a period of at least $20 \mathrm{~s}$ through soft polyethylene tubing (Intramedic Clay Adams Brand; outer diameter, $0.61 \mathrm{~mm}$, inner diameter $0.28 \mathrm{~mm}$ ) (Becton Dickinson) attached to a 30 gauge needle on a $1 \mathrm{ml}$ tuberculin syringe. After injection the catheter was immediately withdrawn and the mice were placed in a recovery chamber prior to being placed back in their cages. Twentyfour hours post-inoculation the mice were euthanized by exposure to excess methoxyfluorane. The bladder and kidneys from each mouse were extracted and separately homogenized in $0.5 \mathrm{ml}$ sterile saline. The tissue was disrupted with 10 strokes, a cooling period on ice, and 10 additional strokes using a Potter-Elvehjem tissue grinder. The grinder included a sintered glass vessel with a PTFE-tipped steel pestle, the latter mounted in a variable speed drill which was operated at $50-75 \%$ of its maximum speed. The total volume of each homogenate was recorded. Dilutions of each homogenate were spread on LB and/or TTC medium (the two media yielded the same estimates of c.f.u. $\mathrm{ml}^{-1}$ homogenate). Colonies were counted after $24 \mathrm{~h}$ (LB) or $48 \mathrm{~h}$ (TTC) incubation of the plates at $37^{\circ} \mathrm{C}$ and colonization was estimated as numbers of c.f.u. per tissue. The statistical significance of differences in the recovery of bacteria from tissues infected with different $E$. coli strains was evaluated with the Mann-Whitney test (Snedecor \& Cochran, 1980). No bacteria were recovered from the tissues of mice inoculated with sterile saline and no $p u t^{+}$revertants or contaminants were detected with TTC medium.

\section{RESULTS}

\section{Construction of PutPA- and ProP-deficient mutants}

E. coli K-12 (like Salmonella typhimurium) possesses three genetic loci pertinent to the uptake and accumulation of osmoprotectants: putPA, proP and proU. All three loci are present and expressed in E. coli HU734 (Culham et al., 1994). The put operon includes divergently transcribed genes putP and putA. PutP is a $\mathrm{Na}^{+}$-proline symporter which does not accept glycine betaine as substrate (Milner et al., 1987). PutA is the bifunctional enzyme which catalyses the oxidation of proline to glutamic acid (Maloy, 1987). Lesions in putP and $p u t A$ were without effect on osmoprotection of $S$. typhimurium by proline (Csonka, 1981). The put locus was deleted from E. coli HU734 since defects in genetic loci proP and proU are cryptic to simple phenotypic tests in $p u t^{+}$strains of $E$. coli K-12. Derivatives of $E$. coli K12 defective at putP have increased resistance to the toxic proline analogue AC. Those defective at $p u t P$, but not those defective at both putP and putA, are also resistant to analogue DHP (Wood, 1981). We therefore selected bacteria that were resistant to $A C$, screening to identify those which were sensitive to DHP, unable to utilize proline and devoid of proline dehydrogenase activity (see Methods). The presence of the desired deletion $[\triangle(p u t P A) 566]$ in the resulting isolate, strain WG541, was verified by PCR (see Methods).

The sequence of the proP locus from E. coli HU734 (accession no. U75904) was determined to assess its similarity with the E. coli K-12 locus. That analysis revealed only three predicted amino acid differences for ProP, each falling within a different hydrophilic segment of the (putative) protein (the predicted changes were Ala-193 to Glu-193, Tyr-257 to His-257 and Phe-380 to Ser-380). Four single nucleotide differences were found in the $282 \mathrm{bp}$ DNA sequence upstream of proP, one (C $\rightarrow A)$ at the -47 position with respect to $p r o P$ promoter $P 1$ and another $(G \rightarrow A)$ at the -31 position with respect to promoter P2. To remove locus proP from strain WG541, deletion proP218 (extending from 59 bp upstream to $44 \mathrm{bp}$ downstream of the ProP ORF) was created in vitro and a segment of $E$. coli $\mathrm{K}-12$ DNA encompassing that deletion was inserted in vector pCVD442 (Donnenberg \& Kaper, 1991). The resulting plasmid, pDC66, was used to create strain WG671 (WG541 proP218) by allelic replacement. The proP deletion was verified by PCR-based DNA amplification (see Methods).

\section{Activities of transporters PutP, ProP and ProU in E. coli HU734}

In $E$. coli $\mathrm{K}-12$, proline serves as a substrate for transporters PutP, ProP and, to a limited extent, ProU. The $K_{\mathrm{m}}$ values of transporters PutP and ProP for proline are approximately $0.3 \mu \mathrm{M}$ (Wood \& Zadworny, 1979) and $100 \mu \mathrm{M}$ (R. T. Voegele, personal communication), respectively. Proline uptake via transporter ProU is barely detectable in E. coli K-12 (Grothe et al., 1986). $\mathrm{AC}$ and DHP are toxic for E. coli and they serve as substrates for transporters PutP, ProP and ProU. The zone of growth inhibition caused by each compound in the radial streak test is thus directly related to transporter activity (Grothe et al., 1986). DHP is detoxified by proline dehydrogenase (PutA), so putA defects enhance DHP toxicity (Wood, 1981).

As was anticipated on the basis of prior experience with E. coli K-12 derivatives, strains HU734, WG541 and WG671 could be distinguished from one another by examining their patterns of sensitivity to AC and DHP on low and high $\mathrm{NaCl}$ media with the radial streak test (Table 2). The patterns of AC and DHP sensitivity observed for these strains and the corresponding E. coli K-12 derivatives were qualitatively similar. However, larger zones of growth inhibition were attributable to ProU activity ( $p u t P A$ proP strains) and to ProP plus ProU activity (putPA strains) in the derivatives of $E$. coli HU734 than in the derivatives of E. coli K-12.

The proline uptake activities of strains HU734 and WG541 were examined under conditions designed to enhance detection of transporter PutP (low osmolality medium, $10 \mu \mathrm{M}$ proline as transport assay substrate) 
Table 2. AC and DHP sensitivities of E. coli K-12, E. coli HU734 and their derivatives

Zones of growth inhibition $(\mathrm{mm})$ were determined by the radial streak test using $0.5 \mathrm{mg}$ test compound (AC or DHP) per plate containing MOPS medium with glucose $(11 \mathrm{mM})$ as carbon source, with or without $\mathrm{NaCl}(0.3 \mathrm{M})$. The E. coli $\mathrm{K}-12$ strains were WG484 (wild-type), WG444 [WG484 $\Delta(p u t P A) 101]$ and WG445 [WG444 $\Delta$ (proP-mel)212]. The E. coli HU734 strains were HU734 (wild-type), WG541 [HU734 $\Delta$ (putPA)566] and WG671 (WG541 proP218).The results are means of 6 determinations (K-12 derivatives) or 18 determinations (HU734 derivatives) \pm SEM.

\begin{tabular}{|c|c|c|c|c|c|c|}
\hline \multirow{2}{*}{$\begin{array}{l}\text { Test compound } \\
\text { and medium }\end{array}$} & \multicolumn{3}{|c|}{ Genotypes of K-12 strains: } & \multicolumn{3}{|c|}{ Genotypes of HU734 strains: } \\
\hline & $\begin{array}{l}\text { Wild- } \\
\text { type }\end{array}$ & $p u t P A$ & $\begin{array}{c}\text { putPA } \\
\text { proP }\end{array}$ & $\begin{array}{l}\text { Wild- } \\
\text { type }\end{array}$ & $p u t P A$ & $\begin{array}{r}\text { putPA } \\
\text { proP }\end{array}$ \\
\hline $\mathrm{AC}(-\mathrm{NaCl})$ & $17 \pm 2$ & $0 \pm 0$ & $0 \pm 0$ & $16 \pm 1$ & $3 \pm 1$ & $2 \pm 1$ \\
\hline $\mathrm{DHP}(-\mathrm{NaCl})$ & $14 \pm 1$ & $15 \pm 2$ & $0 \pm 0$ & $17 \pm 1$ & $15 \pm 1$ & $9 \pm 1$ \\
\hline $\mathrm{AC}(+\mathrm{NaCl})$ & $23 \pm 1$ & $24 \pm 2$ & $17 \pm 4$ & $37 \pm 1$ & $37 \pm 1$ & $27 \pm 3$ \\
\hline $\mathrm{DHP}(+\mathrm{NaCl})$ & $15 \pm 2$ & $21 \pm 2$ & $10 \pm 2$ & $25 \pm 2$ & $32 \pm 2$ & $26 \pm 2$ \\
\hline
\end{tabular}

Table 3. Proline uptake activities of $E$. coli HU734 and its derivatives

E. coli strains were HU734 (wild-type), and derivatives WG541 [HU734 $\Delta$ (putPA)566] and WG671 (WG541 proP218). The results [in $\mathrm{nmol} \mathrm{min}^{-1}\left(\mathrm{mg}\right.$ protein) ${ }^{-1}$ ] are means of three determinations \pm SEM for representative experiments. NT, not tested.

\begin{tabular}{|lcccc|}
\hline \multirow{2}{*}{$\begin{array}{l}\text { Growth medium } \\
\text { supplement }\end{array}$} & $\begin{array}{c}\text { Proline concn } \\
\text { (assay) }(\mu \mathrm{M})\end{array}$ & \multicolumn{3}{c|}{ HU734 genotypes: } \\
\cline { 3 - 5 } & & Wild-type & putPA & putPA proP \\
\hline None & 10 & $18 \pm 1$ & $1 \cdot 5 \pm 0 \cdot 1$ & NT \\
None & 200 & NT & $10 \pm 1$ & $5 \pm 1$ \\
$\mathrm{NaCl}(0.3 \mathrm{M})$ & 200 & NT & $133 \pm 2$ & $12 \pm 2$ \\
\hline
\end{tabular}

(Table 3). As for E. coli $\mathrm{K}-12$, the putPA deletion reduced proline uptake by strain WG541, measured under these conditions, to a low level. The proline uptake activities of strains WG541 and WG671 were examined under conditions designed to enhance detection of transporter ProP (low and high osmolality medium, $200 \mu \mathrm{M}$ proline as transport assay substrate) (Table 3). The residual, $\mathrm{NaCl}$-inducible proline uptake activity present in E. coli WG671 was likely due to transporter ProU. For an analogous E. coli K-12 derivative cultured under similar, high-salt conditions, the activity attributable to ProU was only $0 \cdot 2 \mathrm{nmol} \mathrm{min}{ }^{-1}$ (mg cell protein) ${ }^{-1}$ (Grothe et al., 1986). The activity of transporter ProP could be computed by subtracting that measured in strain WG671 (proP) from that measured in strain WG541 $\left(\right.$ proP $\left.^{+}\right)$. On that basis ProP activity rose 24-fold (from $5 \mathrm{nmol} \mathrm{m^{-1 }}$ (mg protein $)^{-1}$ to $121 \mathrm{nmol} \mathrm{min}^{-1}$ (mg protein) ${ }^{-1}$ when the bacteria were cultured in $\mathrm{NaCl}$-supplemented medium. The ProP activity of $E$. coli K-12 cells cultured in the same, $\mathrm{NaCl}$-containing medium with $\mathrm{D}$-fructose or glycerol as carbon source was less than $50 \mathrm{nmol} \mathrm{min}{ }^{-1}$ (mg protein) $)^{-1}$ (Grothe et al., 1986). These data confirmed the successful isolation of bacteria deficient in transporters PutP and ProP, also indicating that tran- sporters ProP and ProU may be more active in E. coli HU734 than they are in E. coli K-12.

\section{Salt tolerance of E. coli HU734 and its derivatives}

The salt tolerance of $E$. coli HU734 was compared with that of E. coli WG484 (K-12 srl-300::Tn10) by examining their growth rates in $\mathrm{NaCl}$-supplemented MOPS minimal medium (Fig. 1). Although the two strains showed similar growth rates in unsupplemented medium $\left(0.340 \pm 0.004 \mathrm{~h}^{-1}\right.$ and $0.370 \pm 0.004 \mathrm{~h}^{-1}$, respectively (mean \pm standard deviation for four replicates), $E$. coli HU734 was more salt-sensitive than E. coli K-12. The $\mathrm{NaCl}$ concentrations required to reduce the growth rates of these strains twofold were approximately $0.2 \mathrm{M}$ and $0.5 \mathrm{M}$, respectively. The corresponding values for growth in medium supplemented with the osmoprotectant glycine betaine $(1 \mathrm{mM})$ were approximately $0.55 \mathrm{M} \mathrm{NaCl}$ (HU734) and $0.8 \mathrm{M} \mathrm{NaCl}$ (WG484). The effect of glycine betaine concentration (range $25 \mu \mathrm{M}-1 \mathrm{mM}$ ) on growth rate was examined for strain HU734 in medium supplemented with $0.4 \mathrm{M} \mathrm{NaCl}$. Full growth stimulation (from negligible growth to a rate of $0.215 \pm 0.005 \mathrm{~h}^{-1}$ ) was observed at the lowest glycine betaine concentration tested. When a similar experiment 


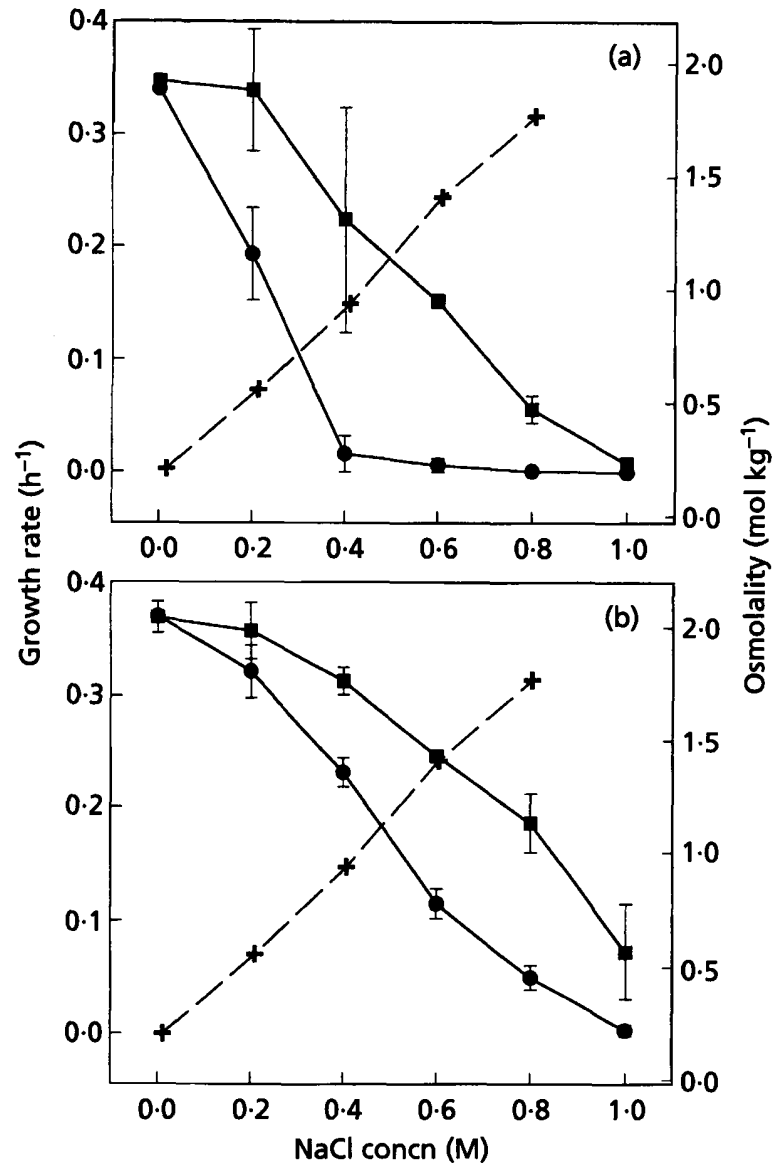

Fig. 1. Growth of $E$. coli in MOPS medium as a function of osmolality and glycine betaine supplementation. $E$. coli HU734 (a) and $E$. coli WG484 (b) (a K-12 derivative) were cultured, with shaking, in MOPS minimal medium as described in Methods. The osmolality $(+)$ of the growth medium was varied, as indicated, by addition of $\mathrm{NaCl}$. Glycine betaine was absent (O) or present $(1 \mathrm{mM})(\mathrm{G})$. Growth rates are reported as means \pm SD for four replicate growth rate determinations.

was performed with strain WG484 (glycine betaine range $62.5 \mu \mathrm{M}-1 \mathrm{mM}, 0.6 \mathrm{M} \mathrm{NaCl}$ ) full growth stimulation (from $0.11 \pm 0.02 \mathrm{~h}^{-1}$ to $0.208 \pm 0.005 \mathrm{~h}^{-1}$ ) was again observed at the lowest glycine betaine concentration tested. Strains HU734, WG541 and WG671 grew at the same rate in MOPS medium (data not shown). Their ability to grow in hypersaline medium [MOPS plus $0.4 \mathrm{M} \mathrm{NaCl}$ (osmolality $0.94 \mathrm{~mol} \mathrm{~kg}^{-1}$ )] with or without glycine betaine $(0 \cdot 1 \mathrm{mM})$ was also tested (Table 4). The growth rates of the three strains in glycine-betaine-supplemented medium were indistinguishable, indicating that mutations $\Delta(p u t P A) 566$ and proP218 were without effect on osmoprotection under these conditions, perhaps because transporter ProU was active.

Bacterial growth in human urine was also assessed. $E$. coli HU734 grew at similar rates in hypertonic human urine (Fig. 2) and in betaine-supplemented, defined medium of similar osmolality (Fig. 1, Table 4). Growth rates in human urine were $0.29 \mathrm{~h}^{-1}$ for urine with
Table 4. Stimulation of growth of E. coli HU734 and its derivatives by glycine betaine in hypertonic media

E. coli HU734 wild-type and derivatives WG541 [HU734 $\Delta(p u t P A) 566$ ] and WG671 (WG541 proP218) were cultured, with shaking, in $\mathrm{NaCl}$-supplemented MOPS minimal medium $\left[0.4 \mathrm{M} \mathrm{NaCl}\right.$ (osmolality $0.94 \mathrm{~mol} \mathrm{~kg}^{-1}$ )] without or with glycine betaine $(0.1 \mathrm{mM})$. The results $\left(\right.$ in $\left.^{-1}\right)$ are means of three determinations \pm SEM for three replicate experiments.

\begin{tabular}{|lccc|}
\hline \multirow{2}{*}{$\begin{array}{l}\text { Glycine } \\
\text { betaine }\end{array}$} & \multicolumn{3}{c|}{ HU734 genotypes: } \\
\cline { 2 - 4 } & Wild-type & putP $A$ & putP $A$ proP \\
\hline- & $0.070 \pm 0.006$ & $0.010 \pm 0.003$ & $0.010 \pm 0.002$ \\
+ & $0.28 \pm 0.02$ & $0.28 \pm 0.02$ & $0.26 \pm 0.03$ \\
\hline
\end{tabular}

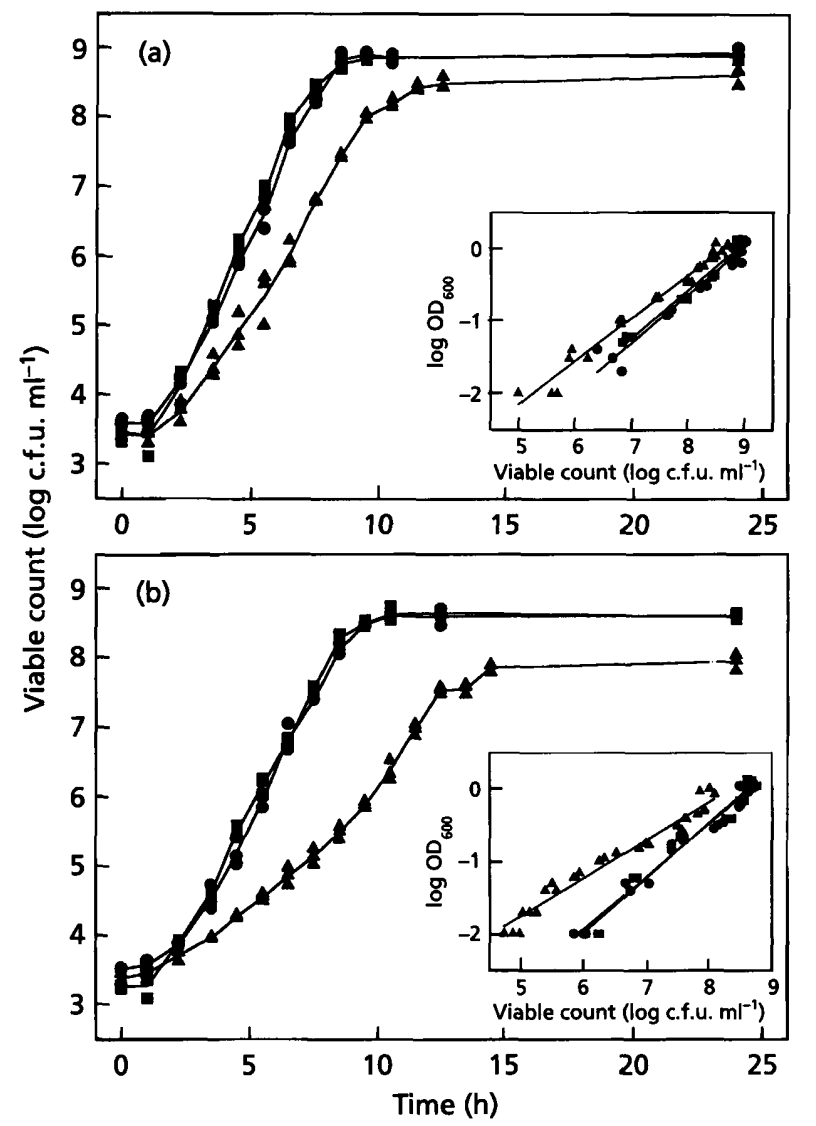

Fig. 2. Effects of transporter defects on growth of $E$. coli in human urine. Growth of $E$. coli strains HU734 ( $\square$ ), WG541 (putP, $)$ and WG671 (putP proP, $\Delta$ ) in hypertonic human urine was estimated by dilution plating (c.f.u. $\mathrm{ml}^{-1}$ ) and measurement of $\mathrm{OD}_{600}$ as described in Methods. (a) Pooled urine, pH 5.79, osmolality $0.80 \mathrm{~mol} \mathrm{~kg}^{-1}$; (b) pooled urine, pH 5.73, osmolality 0.95 mol kg-1. Insets show relationships between viable count and $\mathrm{OD}_{600}$.

osmolality of $0.80 \mathrm{~mol} \mathrm{~kg}^{-1}$ and $\mathrm{pH} 5 \cdot 79$, and $0.27 \mathrm{~h}^{-1}$ for urine with osmolality of $0.95 \mathrm{~mol} \mathrm{~kg}^{-1}$ and $\mathrm{pH} 5.73$, estimated from plots of $\log \mathrm{OD}_{600}$ versus time for 


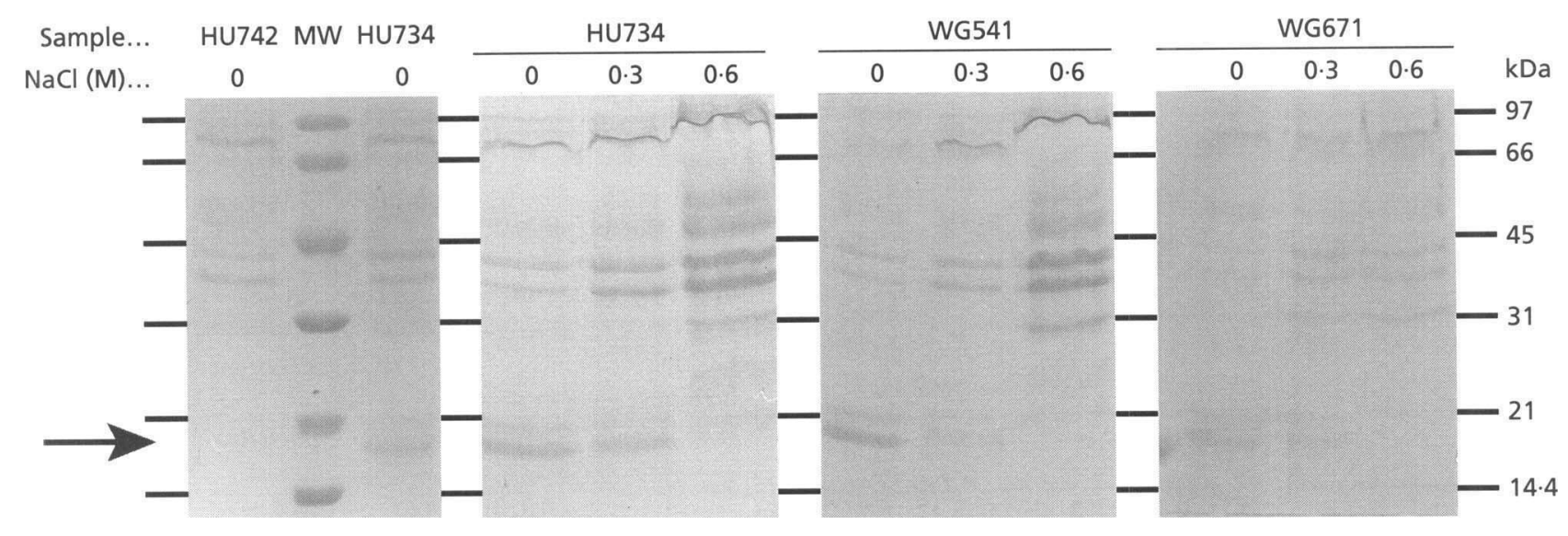

Fig. 3. Effects of osmolality and transporter defects on P pilus expression. Crude pilus extracts from E. coli strains HU734 (pap ${ }^{+}$put $P^{+}$pro $\left.P^{+}\right)$, HU742 (pap put $P^{+}$proP $\left.P^{+}\right)$, WG541 (pap ${ }^{+}$putP proP $P^{+}$) and WG671 (pap ${ }^{+}$putP proP) were analysed by SDS-PAGE as described in Methods. Bacteria were cultured in LB medium to which no additional $\mathrm{NaCl}$ (osmolality $\left.0.4 \mathrm{~mol} \mathrm{~kg}^{-1}\right), 0.3 \mathrm{M} \mathrm{NaCl}\left(1.0 \mathrm{~mol} \mathrm{~kg}{ }^{-1}\right)$ or $0.6 \mathrm{M} \mathrm{NaCl}\left(1.6 \mathrm{~mol} \mathrm{~kg}^{-1}\right)$ was added. Each loaded sample was an extract from approximately $10^{10}$ bacteria. MW, molecular mass markers. The arrow indicates the position of PapA protein bands with apparent molecular masses of $20 \mathrm{kDa}$ and $22 \mathrm{kDa}$, which were evident upon analysis of extracts from strains HU734, WG541 and WG671, but not that from strain HU742 (pap).

periods of exponential growth within the $\mathrm{OD}_{600}$ range $0 \cdot 1-1 \cdot 0$. Whereas the putPA lesion was without effect on growth in urine, the proP lesion impaired growth to a degree that was more pronounced in the urine of higher osmolality (Fig. 2). The relationship between $\mathrm{OD}_{600}$ and viable count [c.f.u. ( $\mathrm{ml}$ culture) ${ }^{-1}$ ] for strain WG671 (putPA proP) differed from that for strains HU734 and WG541 (putPA). The $\mathrm{OD}_{600}$ values for cultures of strain WG671 were higher than those of strains HU734 and WG541 for equivalent viable counts, again to a degree which was greater in the urine of higher osmolality (Fig. 2 , insets). This difference suggests that bacteria with reduced compatible solute uptake activity are dehydrated, having a higher refractive index than their counterparts, and/or that they differ in size, being larger (longer) than their counterparts.

\section{Effects of osmolality on P piliation of E. coli HU734 and its derivatives}

Effects of growth medium osmolality, glycine betaine supplementation and transporter lesions on $\mathrm{P}$ piliation of strain HU734 were assessed with a haemagglutination assay designed to detect expression of the $\mathrm{P}$ pilus adhesin, PapG (see Methods). Whereas cells of strain HU734 cultured to stationary phase in LB medium (shaken or non-shaken) mediated mannose-resistant haemagglutination (MRHA), those cultured to stationary phase in MOPS minimal medium, shaken or nonshaken, did not. By analogy with a previous report (Kunin et al., 1994), the MRHA titre of E. coli HU734 decreased from $1 / 32$ for cells cultured in non-shaken LB medium $\left(0.4 \mathrm{~mol} \mathrm{~kg}^{-1}\right)$ to $1 / 8$ for those cultured in LB plus $0.3 \mathrm{M} \mathrm{NaCl}\left(1.0 \mathrm{~mol} \mathrm{~kg}^{-1}\right)$. Cells cultured in LB medium plus $0.6 \mathrm{M} \mathrm{NaCl}\left(1.6 \mathrm{~mol} \mathrm{~kg}{ }^{-1}\right)$ did not mediate MRHA. The MRHA titres for strains WG541 (putPA) and WG671 (WG541 proP) were $1 / 16$ and $1 / 8$, respectively, for LB-grown bacteria and $1 / 2$ after culture in LB plus $0.3 \mathrm{M} \mathrm{NaCl}$. Neither mediated MRHA after cultivation in LB plus $0.6 \mathrm{M} \mathrm{NaCl}$. Electrophoretic analysis of crude pilus extracts revealed that major pilus protein PapA followed similar trends (Fig. 3). These data indicated only small effects of the putPA and proP deletions on pilus expression; osmoprotection mediated by ProP did not strongly attenuate the adverse effect of elevated salinity on $P$ piliation.

\section{Colonization of the murine urinary tract by $E$. coli HU734 and its derivatives}

Mice and non-human primates provide the preferred animal models for ascending infection of unobstructed human urinary tracts (Johnson \& Russell, 1996). Urine from female CBA mice was found to contain $674 \pm 93 \mu \mathrm{M}$ proline betaine and $687 \pm 204 \mu \mathrm{M}$ glycine betaine (means \pm standard deviations for determinations made on five independent samples) (M. Lever, personal communication). These levels are significantly higher than those of urine from human subjects (mean betaine levels $298 \pm 687 \mu \mathrm{M}$ and $78 \pm 65 \mu \mathrm{M}$, respectively) but similar to those of urine from other mammals (Lever $e t$ al., 1994a). They confirm the availability of betaines to serve as osmoprotectants during analyses of ascending urinary tract infection performed with the murine model.

The numbers of colony forming units (as $\log$ c.f.u.) recovered from the bladders and kidneys of CBA mice inoculated with E. coli strains WG541 $\left(\right.$ proP $\left.P^{+}\right)$and WG671 (proP) are compared in Fig. 4. The numbers of c.f.u. recovered from tissues infected with strain WG541 were similar to those previously reported for infection of 


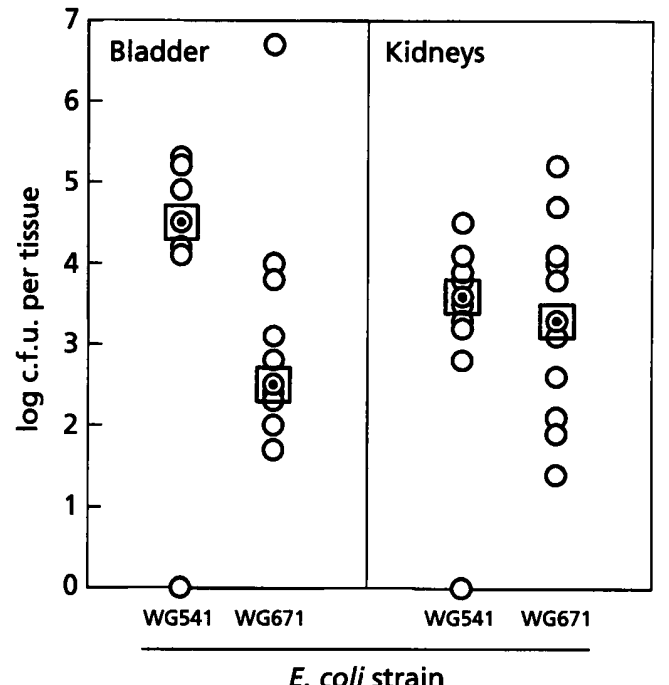

Fig. 4. Colonization of the murine urinary tract by $E$. coli. Each open circle represents the log c.f.u. bacteria recovered per tissue (bladder or two kidneys) of one or more CBA mice (see Methods). Eleven animals were inoculated with each $E$. coli strain [WG541 (putP) or WG671 (putP proP)]. No bacteria were recovered from the bladder or kidneys of a single animal infected with $E$. coli WG541 and these results were taken as 1 c.f.u. per tissue (log c.f.u. $=0$ ). Open squares with central dots represent median values.

CBA mice with E. coli HU734 (Hagberg et al., 1983a), confirming our successful implementation of the murine model. Strain WG671 $[\Delta($ putPA)566 proP218] was recovered from murine bladders at a level 100 -fold lower than strain WG541 $[\Delta(p u t P A) 566]$ (significant at the $95 \%$ confidence level according to the Mann-Whitney test) (Snedecor \& Cochran, 1980; Mobley et al., 1993). However, no significant difference in recovery of the two strains from murine kidneys was detected.

\section{DISCUSSION}

Kunin (1987) suggested that osmolality fluctuations influence the survival and growth of $E$. coli in the human urinary tract. This report extends our analyses of osmoregulation by human pyelonephritis isolate HU734 and the relationship between osmoadaptation and colonization of the urinary tract by $E$. coli. Deletion of genetic loci putPA and proP from the chromosome of $E$. coli HU734 facilitated characterization of its transporter activities and examination of their impact on colonization of the murine urinary tract. Like E. coli K-12, E. coli HU734 expresses transporters PutP, ProP and ProU. Osmotic induction yielded ProP activity in E. coli HU734 that was threefold higher than that of E. coli $\mathrm{K}-12$ (Tables 2, 3). It will be of interest to determine whether that elevation is related to differences in DNA sequence between the proP loci of E. coli K-12 and E. coli HU734 and whether it is common among urinary tract isolates. The activity of transporter ProU also appeared to be elevated in $E$. coli HU734, but that conclusion must be confirmed by deletion of the proU locus and comparison of the glycine betaine uptake activities of $p r o U^{+}$and proU bacteria.

Deletion of transporters PutP and ProP had no effect on the growth rate of $E$. coli HU734 in hypertonic minimal medium with or without glycine betaine (Table 4). In analogous studies on $S$. typhimurium, lesions in both proP and proU were required to abolish osmoprotection by glycine betaine. A lesion in either locus reduced but did not eliminate osmoprotection (Dunlap \& Csonka, 1985). Deletion of transporter ProP did impair bacterial growth in hypertonic human urine (Fig. 2) and it reduced the numbers of bacteria recovered from the bladders of inoculated mice 100 -fold. However, recovery of bacteria from the kidneys was unaffected (Fig. 4). The effect of the proP lesion on bladder colonization suggests that transporter ProP is expressed by bacteria in the bladder and that osmoprotective betaine uptake facilitates survival and/or growth of bacteria which inhabit that tissue. If transporter ProU is also expressed and active in the urinary tract, bacteria defective at both proP and proU may be further impaired in their ability to proliferate in that environment.

Why did the proP lesion influence the recovery of bacteria from the bladders but not the kidneys of infected mice? The balance between proliferation through growth and cell division versus loss through death and micturition is expected to be more critical to population density for free than for surface-bound urinary tract bacteria (Gordon \& Riley, 1992). Reductions in bacterial growth rate due to high osmolality and/or a ProP defect would influence bacterial population density in the bladder more than in the kidney if a smaller fraction of the bacteria in the bladder than the kidney were surface-associated. Adhesion of E. coli to uroepithelial cells is believed to be mediated, at least in part, by $P$ pili. $P$ pilus expression [both PapG (see Results) and PapA (Fig. 3) were impaired when the bacteria were cultured in $\mathrm{NaCl}$-supplemented LB media with osmolalities in excess of $1 \mathrm{~mol} \mathrm{~kg}^{-1}$ ]. If the expression of $\mathrm{P}$ pili within the urinary tract shows a similar dependence on urine osmolality, P-pilus-mediated bacterial adhesion may also be impaired by urine osmolality within the normal murine (up to $3 \mathrm{~mol} \mathrm{~kg}^{-1}$ ) or human $\left(0.04-1.3 \mathrm{~mol} \mathrm{~kg}^{-1}\right)$ range. However, osmoprotection mediated by transporter ProP did not significantly attenuate the inhibition of $P$ pilus expression by high salinity (Fig. 3).

Why did the proP lesion reduce the recovery of E. coli HU734 from the murine bladder (Fig. 4) and its growth rate in hypertonic human urine (Fig. 2) but not its growth rate in a hypertonic minimal medium (Table 4) ? A number of important characteristics differentiate the conditions faced by bacteria in the bladder (in vivo), during urine culture (in vitro) and during minimal medium culture (in vitro). They include: (1) microaerophily [in vivo (Maluszynska et al., 1992)] versus aerobiosis (in vitro); (2) the presence (in vivo, and in urine culture in vitro) versus the absence (in minimal 
medium in vitro) of urea; (3) potentially variable (in vivo) versus constant (in vitro) osmolality; (4) a mixture of organic substituents (in vivo, and in urine culture in vitro) versus single carbon (glucose) and nitrogen $\left(\mathrm{NH}_{4} \mathrm{Cl}\right.$ ) sources provided in excess (in minimal medium in vitro); (5) continuous (in vivo) versus batch (in vitro) culture; and (6) a combination of surface-bound and suspension culture (in vivo) versus suspension culture (in vitro). During our efforts to characterize the transporter activities of $E$. coli HU734 and its derivatives, the bacteria were cultured under conditions which would permit comparison of the resulting data with properties previously reported for E. coli K-12. Relatively little information is available concerning the impact of the listed culture conditions on osmoprotective compatible solute uptake, but the potential roles of aeration and urea content merit particular attention.

Anaerobiosis attenuated the sensitivity of E. coli K-12 to toxic proline analogues AC and DHP under both lowand high-salt conditions, implying reduced activity of transporter PutP, ProP and/or ProU (Reese et al., 1996). However, the relative impact of anaerobiosis on the activities of those transporters, or indeed on others whose activities are also expected to depend on cellular energy status, was not reported.

Urea can reach concentrations of $0.5 \mathrm{M}$ and $1.5 \mathrm{M}$ in human and rat urine, respectively. Since most biological membranes are urea-permeable, urea is not expected to alter the distribution of water across bacterial cell membranes. Urea, alone, did not elicit uptake of glycine betaine or proline betaine by $E$. coli and neither glycine betaine nor proline betaine stimulated the growth of E. coli in urea-supplemented media unless $\mathrm{NaCl}$ levels were also high (Chambers \& Kunin, 1985; Randall et al., 1996). Those observations are consistent with known requirements for the activation of transporters ProP and ProU and the assumption that the cytoplasmic membrane of E. coli is urea-permeable (Csonka \& Epstein, 1996). They suggest that, in considering its capacity to elicit an osmoregulatory response from $E$. coli, the osmolality of urine should be corrected for the contribution of urea. Thus normal human urine would vary in 'corrected' osmolality within the range of standard growth media $\left(0.2-0.4 \mathrm{~mol} \mathrm{~kg}^{-1}\right)$ and the maximum 'corrected' osmolalities of human and murine urines would be less than $1 \mathrm{~mol} \mathrm{~kg}^{-1}$ and $1.5 \mathrm{~mol} \mathrm{~kg}^{-1}$, respectively. These corrected values fall within the range of the (urea-free) minimal medium used here to test effects of osmolality, glycine betaine and transporter ProP on bacterial growth rate (Fig. 1, Table 4). Although urea alone does not elicit osmoregulatory betaine uptake, cytoplasmic glycine betaine alleviates the inhibition of bacterial growth by urea (Chambers \& Kunin, 1985; Randall et al., 1996). It is thus possible that the activity of transporter ProP assumes more importance for bacterial growth in the bladder than in ureafree, in vitro culture because its activity attenuates effects of urea on bacterial growth rate.

The activities of transporters ProP and ProU respond to the osmolality of the extracellular medium; ProP ac- tivity, at least, also responds to other signals. Transcription of loci proP and proU is enhanced when bacteria are cultured in high osmolality media; proP transcription is and proU transcription may also be increased during stationary-phase growth (Csonka \& Epstein, 1996). As noted above, both ProP and ProU are activated when bacteria are subjected to an osmotic upshift. Although urine osmolality is likely to be important, further investigation will be required to fully define which stimuli elicit osmoprotective activity in bacteria that colonize the murine bladder.

Lever et al. (1994a, b) examined the betaine content of serum and urine as a function of the age, sex and health status of human subjects. In normal humans urinary glycine betaine levels were $78 \pm 65 \mu \mathrm{M}$ (median $67 \mu \mathrm{M}$, range $5 \mu \mathrm{M}-405 \mu \mathrm{M})$; those of proline betaine were $298 \pm 687 \mu \mathrm{M}$ (median $96.5 \mu \mathrm{M}$, range from not detectable to $5 \cdot 14 \mathrm{mM}$ ). Mice and other mammals have higher urinary glycine betaine and proline betaine levels than humans (Lever et al., 1992, 1994a). Maximal stimulation of the growth rate of E. coli HU734 in hypertonic minimal medium was observed with glycine betaine at levels as low as $25 \mu \mathrm{M}$ (see Results). The glycine betaine levels in the urine of healthy humans (and mice) are therefore unlikely to limit the ability of $E$. coli to respond to urine concentration by using glycine betaine as an osmoprotectant. It has been suggested that toxic betaine analogues recognized by bacterial but not host transporters may serve as antibacterial agents for the treatment of urinary tract infection (Chambers et al., 1987). These data suggest that particular attention should be paid to the substrate specificity of transporter ProP in pursuing that concept.

The inhibition of bacterial growth in human urine (Fig. 2) and the reduction in colonization of the murine bladder (Fig. 4), both due to a proP lesion, offer the first direct evidence that osmoprotective betaine accumulation and transporter ProP are pertinent to urinary tract colonization by E. coli. In view of its high osmolality, rodent urine may impose a greater barrier to the growth of $E$. coli than human urine. The murine model should thus be regarded as a particularly sensitive one for the detection of osmolality effects on urinary tract colonization.

\section{ACKNOWLEDGEMENTS}

We are grateful to Sheila I. Hull (for pAGK2), Michael F. Hynes (for pJQ200mp18) and James B. Kaper (for pCVD442) for plasmids and advice regarding their use; to Michael Lever, Warwick Dellow and Ralf T. Voegele for access to unpublished data; to Adam Reilly for technical assistance; and to the Kidney Foundation of Canada for financial support.

\section{REFERENCES}

Bochner, B. R. \& Savageau, M. A. (1977). Generalized indicator plate for genetic, metabolic, and taxonomic studies with microorganisms. Appl Environ Microbiol 33, 434-444.

Chambers, S. \& Kunin, C. M. (1985). The osmoprotective properties of urine for bacteria: the protective effect of betaine and 
human urine against low $\mathrm{pH}$ and high concentrations of electrolytes, sugars, and urea. J Infect Dis 152, 1308-1316.

Chambers, S. T. \& Kunin, C. M. (1987). Osmoprotective activity for Escherichia coli in mammalian renal inner medulla and urine. Correlation of glycine and proline betaines and sorbitol with response to osmotic loads. J Clin Invest 80, 1255-1260.

Chambers, S. T., Kunin, C. M., Miller, D. \& Hamada, A. (1987). Dimethylthetin can substitute for glycine betaine as an osmoprotectant molecule for Escherichia coli. J Bacteriol 169, 4845-4847.

Csonka, L. N. (1981). Proline overproduction results in enhanced osmotolerance in Salmonella typhimurium. Mol Gen Genet 182, 82-86.

Csonka, L. N. \& Epstein, W. (1996). Osmoregulation. In Escherichia coli and Salmonella: Cellular and Molecular Biology, 2nd edn., pp. 1210-1223. Edited by F. C. Neidhardt and others. Washington, DC: American Society for Microbiology.

Culham, D. E., Lasby, B., Marangoni, A. G., Milner, J. L., Steer, B. A., van Nues, R. W. \& Wood, J. M. (1993). Isolation and sequencing of Escherichia coli gene proP reveals unusual structural features of the osmoregulatory proline/betaine transporter, ProP. J Mol Biol 229, 268-276.

Culham, D. E., Emmerson, K. S., Lasby, B., Mamelak, D., Steer, B. A., Gyles, C. L., Villarejo, M. \& Wood, J. M. (1994). Genes encoding osmoregulatory proline/glycine betaine transporters and the proline catabolic system are present and expressed in diverse clinical Escherichia coli isolates. Can J Microbiol 40, 397-402.

Donnenberg, M. S. \& Kaper, J. B. (1991). Construction of an eae deletion mutant of enteropathogenic Escherichia coli by using a positive-selection suicide vector. Infect Immun 59, 4310-4317.

Donnenberg, M. S. \& Welch, R. A. (1996). Virulence determinants of uropathogenic Escherichia coli. In Urinary Tract Infections: Molecular Pathogenesis and Clinical Management, pp. 135-174. Edited by H. L. T. Mobley \& J. W. Warren. Washington, DC: American Society for Microbiology.

Dunlap, V. J. \& Csonka, L. N. (1985). Osmotic regulation of Lproline transport in Salmonella typhimurium. J Bacteriol 163, 296-304.

Gordon, D. M. \& Riley, M. A. (1992). A theoretical and experimental analysis of bacterial growth in the bladder. Mol Microbiol 6, 555-562.

Graham, S. B., Stephenson, J. T. \& Wood, J. M. (1984). Proline dehydrogenase from Escherichia coli K12. Reconstitution of a functional membrane association. J Biol Chem 259, 2656-2661.

Grothe, S., Krogsrud, R. L., McClellan, D. J., Milner, J. L. \& Wood, J. M. (1986). Proline transport and osmotic stress response in Escherichia coli K-12. J Bacteriol 166, 253-259.

Hagberg, L., Engberg, I., Freter, R., Lam, J., Olling, S. \& Svanborg Eden, C. (1983a). Ascending, unobstructed urinary tract infection in mice caused by pyelonephritogenic Escherichia coli of human origin. Infect Immun 40, 273-283.

Hagberg, L., Hull, R., Hull, S., Falkow, S., Freter, R. \& Svanborg Eden, C. (1983b). Contribution of adhesion to bacterial persistence in the mouse urinary tract. Infect Immun 40, 265-272.

Herrero, M., de Lorenzo, V. \& Timmis, K. N. (1990). Transposon vectors containing non-antibiotic resistance selection markers for cloning and stable chromosomal insertion of foreign genes in gram-negative bacteria. J Bacteriol 172, 6557-6567.

Johnson, D. E. \& Russell, R. G. (1996). Animal models of urinary tract infection. In Urinary Tract Infections: Molecular Pathogensis and Clinical Management, pp. 377-403. Edited by H. L. T.
Mobley \& J. W. Warren. Washington, DC: American Society for Microbiology.

Klann, A. G., Hull, R. A. \& Hull, S. I. (1992). Sequences of the genes encoding the minor tip components of Pap-3 pili of Escherichia coli. Gene 119, 95-100.

Kunin, C. M. (1987). Detection, Prevention \& Management of Urinary Tract Infections. 4th edn. Philadelphia: Lea \& Febiger.

Kunin, C. M., Hua, T. H., Van Arsdale White, L. \& Villarejo, M. (1992). Growth of Escherichia coli in human urine: role of salt tolerance and accumulation of glycine betaine. J Infect Dis $\mathbf{1 6 6}$, 1311-1315.

Kunin, C. M., Hua, T. H., Guerrant, R. L. \& Bakaletz, L. O. (1994). Effect of salicylate, bismuth, osmolytes, and tetracycline resistance on expression of fimbriae by Escherichia coli. Infect Immun 62, 2178-2186.

Laemmli, U. K. (1970). Cleavage of structural proteins during the assembly of the head of bacteriophage T4. Nature 227, 680-685.

Lever, M., Bason, L., Leaver, C., Hayman, C. M. \& Chambers, S. T. (1992). Same-day batch measurement of glycine betaine, carnitine, and other betaines in biological material. Anal Biochem 205, 14-21.

Lever, M., Sizeland, P. C., Bason, L. M., Hayman, C. M. \& Chambers, S. T. (1994a). Glycine betaine and proline betaine in human blood and urine. Biochim Biophys Acta 1200, 259-264.

Lever, M., Sizeland, P. C., Bason, L. M., Hayman, C. M., Robson, R. A. \& Chambers, S. T. (1994b). Abnormal glycine betaine content of the blood and urine of diabetic and renal patients. Clin Chim Acta 230, 69-79.

Loeb, W. F. \& Quimby, F. W. (1989). The Clinical Chemistry of Laboratory Animals. NY: Pergamon Press.

McMichael, J. C. \& Ou, J. T. (1979). Structure of common pili from Escherichia coli. J Bacteriol 138, 969-975.

Maloy, S. R. (1987). The proline utilization operon. In Escherichia coli and Salmonella typhimurium: Cellular and Molecular Biology, pp. 1513-1519. Edited by F. C. Neidhardt and others. Washington, DC: American Society for Microbiology.

Maluszynska, G. M., Magnusson, K. E. \& Rosenquist, A. (1992). Reduced environmental redox potential affects both transcription and expression of the pap pili gene. Microb Ecol Health Dis 5, 257-267.

Mamelak, D. (1994). The application of genetic and molecular biological techniques to the pyelonephritis isolate Escherichia coli HU734 and colonization studies in the murine urinary tract. MSc thesis, University of Guelph.

Miller, J. H. (1972). Experiments in Molecular Genetics. Cold Spring Harbor, NY: Cold Spring Harbor Laboratory.

Miller, V. L. \& Mekalanos, J. J. (1984). Synthesis of cholera toxin is positively regulated at the transcriptional level by toxR. Proc Natl Acad Sci USA 81, 3471-3475.

Milner, J. L., McClellan, D. J. \& Wood, J. M. (1987). Factors reducing and promoting the effectiveness of proline as an osmoprotectant in Escherichia coli K12. J Gen Microbiol 133, 1851-1860.

Milner, J. L., Grothe, S. \& Wood, J. M. (1988). Proline porter II is activated by a hyperosmotic shift in both whole cells and membrane vesicles of Escherichia coli K12. J Biol Chem 263, 14900-14905.

Mobley, H. L., Jarvis, K. G., Elwood, J. P., Whittle, D. I., Lockatell, C. V., Russell, R. G., Johnson, D. E., Donnenberg, M. S. \& Warren, J. W. (1993). Isogenic P-fimbrial deletion mutants of pyelonephritogenic Escherichia coli: the role of alpha Gal(1-4) beta Gal 
binding in virulence of a wild-type strain. Mol Microbiol 10, 143-155.

Neidhardt, F. C., Bloch, P. L. \& Smith, D. F. (1974). Culture medium for enterobacteria. J Bacteriol 119, 736-747.

Old, D. C. (1985). Haemagglutination methods in the study of Escherichia coli. In The Virulence of Escherichia coli: Reviews and Methods, pp. 287-313. Edited by M. Sussman. London: Academic Press.

Quandt, J. \& Hynes, M. F. (1993). Versatile suicide vectors which allow direct selection for gene replacement in gram-negative bacteria. Gene 127, 15-21.

Randall, K., Lever, M., Peddie, B. A. \& Chambers, S. T. (1995). Competitive accumulation of betaines by Escherichia coli K-12 and derivative strains lacking betaine porters. Biochim Biophys Acta 1245, 116-120.

Randall, K., Lever, M., Peddie, B. A. \& Chambers, S. T. (1996). Accumulation of natural and synthetic betaines by a mammalian renal cell line. Biochem Cell Biol 74, 283-287.

Reese, L. M., Cutler, K. O. \& Deutch, C. E. (1996). Sensitivity of Escherichia coli to proline analogues during osmotic stress and anaerobiosis. Lett Appl Microbiol 22, 202-205.

Ross, D. L. \& Neely, A. E. (1983). Textbook of Urinalysis and Bodily Fluids. Norwalk, VA: Appleton Century Crofts.

Sambrook, J., Fritsch, E. F. \& Maniatis, T. (1989). Molecular
Cloning: a Laboratory Manual, 2nd edn. Cold Spring Harbor, NY: Cold Spring Harbor Laboratory.

Schmidt-Nielsen, B., Graves, B. \& Roth, J. (1983). Water removal and solute additions determining increases in renal medullary osmolality. Am J Physiol 244, F472-F482.

Snedecor, G. W. \& Cochran, W. G. (1980). Statistical Methods 7th edn. Ames, IA: Iowa State University Press.

Warren, J. W. (1996). Clinical presentations and epidemiology of urinary tract infections. Urinary Tract Infections: Molecular Pathogenesis and Clinical Management. pp. 3-27. Edited by H. L. T. Mobley \& J. W. Warren. Washington, DC: American Society for Microbiology.

Wood, J. M. (1981). Genetics of L-proline utilization in Escherichia coli. J Bacteriol 146, 895-901.

Wood, J. M. \& Zadworny, D. (1979). Characterization of an inducible porter required for L-proline catabolism by Escherichia coli K12. Can J Biochem 57, 1191-1199.

van der Woude, M., Braaten, B. \& Low, D. (1996). Epigenetic phase variation of the pap operon in Escherichia coli. Trends Microbiol 4, 5-9.

Received 15 May 1997; revised 28 July 1997; accepted 11 September 1997. 